\title{
OUR CONTRIBUTORS
}

Miss Josefa Saniel is Assistant Professor of History at the University of the Philippines, and an active member of the International Association of Historians of Asia.

David K. Wyatt is a doctoral student at Cornell currently in Thailand on field work.

R. Suntharalingam is a lecturer at the University of Singapore who is at present on two years study leave in London.

M. Ladd Thomas is the co-ordinator of the new Center for Southeast Asian Studies at Dekalb, Northern Illinois.

P. Boyce is a lecturer in Political Science at the University of Tasmania.

Lea E. Williams is the author of Overseas Chinese Nationalism: The Genesis of the Pan-Chinese Movement in Indonesia who has been visiting Asian Foundation Professor at Singapore.

N. R. Jackson was for fourteen years in the Malayan Civil Service in the Chinese Secretariate; he is now Assistant Registrar at Hong Kong University.

J. C. Jackson is a lecturer in Geography at the University of Malaya.

Among the reviewers are: Francis Carnell of Nuffield College of Oxford; Eric Stokes, author of the Utilitarians and India, at the University College of Rhodesia and Nyasaland; K. R. Walker of S.O.A.S London; S. Y. Teng of Indiana; Richard Storry of St. Antony's College, Oxford; Paul Wheatley of the Center for Southeast Asian Studies, Berkeley; D. K. Bassett, J. Frodsham and S. Arasaratmam of the University of Malaya; C. P. Fitzgerald and Emma Sadka at the A.N.U., Canberra; Chu-tu Hsueh of the University of Hong Kong; T. C. Liu of Stanford; Kung-chuan Hsiao of the University of Washington; C. Collin Davies of Balliol; and C. Jack-Hinton of the University of Singapore. 